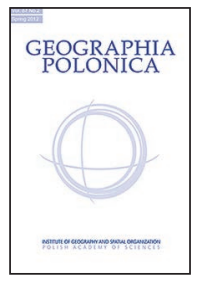

\title{
THE SPREAD OF SARS-COV-2 (COVID-19) AND THE REGIONAL CONNECTIVITY IN WEST KALIMANTAN PROVINCE, INDONESIA
}

\author{
Syaiful Muazir (D) - Lestari (D) - Muhammad Ridha Alhamdani \\ Muhammad Nurhamsyah (D) \\ Department of Architecture, Faculty of Engineering \\ Tanjungpura University \\ Pontianak: Indonesia \\ e-mails: syaifulmuazir@teknik.untan.ac.id (corresponding author) • lestari@teknik.untan.ac.id • Mridhaalhamda- \\ ni@teknik.untan.ac.id・nurhamsyah@teknik.untan.ac.id
}

\begin{abstract}
At the end of 2019, a disease was identified as Severe Acute Respiratory Syndrome Coronavirus 2 or COVID-19. The expected modes of transmission are direct or indirect contact, droplets, and aerosol. The spread of an infection can be also caused by interaction between regions and the proximity to a central transmission area. This article elucidates the connectivity between regions in West Kalimantan in relation to the spread of COVID-19 using network analysis, which shall be superimposed with the data pertaining to the spread of COVID-19. From the findings, Kubu Raya and Pontianak have a high number of COVID-19 cases, especially confirmed ones. Considering their centrality and block measurements, Kubu Raya is featured as region with the highest score (degree: 60.3; closeness: 71.4; betweenness: 75.6; and eigenvector: 82.4), close to Pontianak city as the capital city. When regarded from the context of regional connectivity, both areas serve as the main 'gateways' and 'hubs'. Additionally, the role of each region in urban hierarchy, the number of residents and their proximity to one another also tend to affect the spread of COVID-19.
\end{abstract}

\section{Key words}

COVID-19 • regional connectivity $\bullet$ West Kalimantan $•$ Indonesia

\section{Introduction}

A disease affecting the respiratory tract was identified in Wuhan, Hubei Province, China at the end of 2019. The disease is caused by a new type of coronavirus that is similar to the coronavirus that causes severe acute respiratory syndrome (SARS) (Tan et al., 2020). Eventually, WHO named the disease COVID-19 (Coronavirus Disease 2019) and International Virus Taxonomy Committee named it as Severe Acute Respiratory Syndrome Coronavirus 2 or SARS-CoV-2. This disease rapidly spread to other regions. In January 2020, 
consecutive cases were reported to have occurred in 32 provinces, cities and special administrative regions in China, including Hong Kong, Macau and Taiwan (Wang et al., 2020). It spread to more than 30 countries in two months (Zhao \& Chen, 2020). The disease was soon declared a pandemic due to its worldwide spread.

COVID-19 has a number of symptoms, characteristics and modes of transmission identified through several studies. Fever, cough and fatigue are the most dominant symptoms (Huang et al., 2020; Guan et al., 2020). Respiratory disorder is a severe and fatal symptom that also may occur due to the disease (Chen et al., 2020). From research conducted on patients suffering from this disease at its origin in China, it was estimated that $3.6 \%$ of the cumulative number of patients and $20.6 \%$ of the cumulative number of patients with severe symptoms were at risk (Guan et al., 2020). However, the number of infection and mortality rates in different countries indicated varied data. Most countries located in relatively lower temperature regions saw a rapid increase in COVID-19 cases compared to those with a warmer climate (Mazhar et al., 2020). Transmission of COVID-19 is believed to occur from human to human (Li et al., 2020), but the modes of transmission are still being observed. The expected modes of transmission are direct or indirect contact, droplets and aerosol (Asadi et al., 2020; Worldometer, 2020) The proximity of a region to a central transmission area also has a significant effect on the risk of the spread of COVID-19 (Liu, 2020). Quarantine and regional control have shown effective results in preventing the spread of COVID-19 (Zhao \& Chen, 2020).

COVID-19 has also been spreading in Indonesia. The first positive case in Indonesia was detected on March 2, 2020, when two Indonesian citizens were confirmed to be infected by an infected Japanese national who lived in Malaysia and had tested positive after returning from a trip to Indonesia (Ratcliffe, 2020). Only a month after the first case, on April 9, the COVID-19 pandemic spread to 34 provinces in Indonesia, with East Java, Jakarta and South Sulawesi as the most exposed provinces (Reuters, 2020). On June 26, 2020, East Java officially surpassed DKI Jakarta as the most affected province. As of June 28, 2020, Indonesia has reported 54,010 positive cases, and in terms of death rates, Indonesia is in sixth place in Asia, with 2754 deaths (www.worldometers.info). In anticipating the pandemic, the central government has formed a task force to accelerate the handling of COVID-19 on March 13, 2020. This task force aims to coordinate interagency activities to prevent and mitigate the impact of COVID-19 in Indonesia. Another policy taken by the central government is to implement Large-Scale Social Restrictions (PSBB) or restrictions on certain activities in an area that is suspected of being infected with the corona virus or COVID-19.

One of the provinces in Indonesia is West Kalimantan $\left(147,307 \mathrm{~km}^{2}\right)$. Summarized from the central statistical agency (2020), West Kalimantan is the third biggest provinces in Indonesia, and one of the provinces bordering directly by land to a neighboring country, namely Sarawak-East Malaysia. West Kalimantan also becomes the province with the largest number of border gates in Indonesia, with five border gates facing Sarawak Malaysia. Based on the 2019 population projection, the population of West Kalimantan Province is around five million inhabitants. In 2019 the number of foreign tourists who came was 77,921 visitors. Foreign tourists who come are dominated by foreign tourists from ASEAN countries, reaching more than $90 \%$. This is not surprising because the West Kalimantan region is directly adjacent to Malaysia. Besides, from Kubu Raya, where the international airport located can access directly to the national capital (Jakarta) by air, while other nearby provinces can be accessed directly by air or by land.

In West Kalimantan, measures against COVID-19 began with the issuance of a circular of extraordinary occurrence (KLB) concerning the coronavirus 2019 emergency 
response, dated March 17, 2020, by the governor of West Kalimantan due to the detection in 110 people who were under observation and 15 people who were under surveillance in several regions in West Kalimantan. The initial detection of one patient under surveillance, however, occurred on February 2, 2020. In the middle of March, two positive cases were confirmed-one patient in Pontianak City at Dr. Soedarso hospital and the other in Singkawang at Abdul Aziz hospital. Based on updated data on http://data. kalbarprov.go.id, as of September 30, 2020, Pontianak City is the region with the most number of confirmed cases, followed by Kubu Raya Regency and Ketapang Regency

The spread of an infection (endemic/pandemic) can be caused by several factors, such as movement and connectivity or interaction between regions. In order to facilitate interaction, the regions need to be connected, i.e., there must be ease of movement of humans, materials, or information from one location to another, which is called connectivity (Sokol, 2009). Such connectivity can affect the spread of infection. In several initial discussions from the spatial perspective, it has been stated that the spread of infection can be caused by several factors, such as ease of transportation (Lawyer, 2016), community mobility (Bajardi at al., 2011) and interconnectivity between regions (Tuncer \& Le, 2014; Grais et al., 2003). However, connectivity between regions is needed to support the stream of goods and services for interregional exchange. From West Kalimantan's perspective, this province has the most border gates between countries in Indonesia, reaching five direct border gates with Sarawak, Malaysia. Besides, it is also connected with Central Kalimantan by road and several areas on Java by sea. Supadio international airport is also the busiest airport in Indonesia (https://pariwisataindonesia.id/), which has direct access to Jakarta, even to several countries such as Malaysia and Kuching Sarawak. West Kalimantan is a strategic area if it is seen from the many entrances from several neighboring regions and countries.
With respect to regional connectivity, a measurement can be employed, which considers the presence of a network analysis that consists of nodes and links that can each provide a score for regional connectivity (Sokol, 2009). Downs and Horner (2012) stated that graphic illustration and network analysis approach can be used to analyze inter-location relation in the form of nodes/ vertices and its links/edges. In general, there are at least three basic approaches to network analysis, which can be used to calculate and observe the tendencies in a network (Borgatti et al., 2013), including (1) centrality, (2) subgraph, and (3) equivalence. Based on the introduction provided above, this article would like to elucidate the 'connectivity' between regions in West Kalimantan and describe its relation to the spread of COVID-19. In general, regional connectivity in West Kalimantan is traced through network analysis (by node and by group), which shall be superimposed with the data pertaining to the spread of COVID-19 in West Kalimantan so that positional tendencies of regions in the network and the spread of COVID-19 can be observed.

Related to the spread of infection (endemic/pandemic), several discussions from previous research can become useful references. In general, differences in climate and population are two factors contributing to an endemic (Merler \& Ajelli 2010). On a certain scale, Inaida et al. (2011) stated that an endemic occurs faster in metropolitan areas or regions with large or dense populations, resulting from direct infection from person to person. Merler and Ajelli (2010) stated that spatial and populational configurations have an impact on the spread of a disease. In their discussion, the urban hierarchy tends to determine the spread. For example, a large city can pass an infection to a small city. Additionally, several determining elements of the spread are dictated by population heterogeneity and pattern of community movement and transport. Bajari et al. (2011) added that the spread of infection can be caused by human movement or mobility. On a smaller 
scale in a region, the spread of disease is fast and massive due to several causes such as a large number of families and community members in an environment, who interact in a close physical distance (Milne et al., 2013 In another perspective, in a literary discussion presented by Lawyer (2016), it was stated that the fast spread of an infection is caused by the ease of global transportation. According to Tuncer and Le (2014), as well as Grais et al. (2003), a pandemic can be hastened through the acceleration of interconnectivity between regions and cities through (air) transport. They further stated that if cities or regions are connected, changes in reproduction of the spread between initial regions and destination regions can become more effective. Thus, transportation becomes one of the main factors in the spread of disease. Moreover, a dense population that spreads across neighboring regions is also among the estimated factors of the spread of disease (Dunn \& Atlanta, 1957). Valleron et al. (2010) stated that the hypotheses that may be developed regarding the cause of a pandemic are not only the amount of travel or transport between cities or regions but also the 'connectivity' between cities and their connecting facilities.

By considering how infectious diseases spread through public mobility (movement) and facility (transportation) as well as regional connectivity, a study of interaction between regions can be undertaken to observe the tendencies of regional connectivity and its relationship to the characteristics of affected areas. In the general sense, interaction is interpreted as an exchange, but it can also occur without changing one with the other (Edmonds, 2008). In order to interact, the regions need to be connected, in the sense that there must be ease of movement of human, material, and information from one location to another, which is called connectivity (Sokol, 2009). In its measurement, connectivity has a strong connection with the concept of network analysis that consists of nodes and links that can each provide a score for regional connectivity (Sokol, 2009). Downs and
Horner (2012) stated that graphic illustration and network analysis approach can be used to analyze inter-location relation in the form of nodes/vertices and its links/edges.

Out of the many types and models of analytical approach that can be used to narrow down the perspective, several can be utilized as the basis for network analysis. Adopted from Borgatti et al. (2013), there are at least 3 basic approaches in network analysis that can be used to calculate and observe the tendencies within a network. These approaches are (1) centrality, (2) subgraph and (3) structural equivalence. Centrality is an approach that tries to find the most important point in a network, which is usually present at the most strategic location or position in the network. Subgraph (or subgroup) refers to the actors or points that are interrelated but can be considered to be individual entities while still remaining in a network (Borgatti et al., 2013). According to Borgatti et al. (2013), structural equivalence is a form of direct connection among actors/points. It looks for connected actors/points and identifies based on similarities in position. According to Butts (2008), in relation to network analysis (SNA), there are several software packages which provides support for a range of network analytic functionality. From his description, some software can be used, including those that are commonly used such as UCINET, STRUCTURE, StOCNET, MultiNet and GRADAP, to more specialized applications such as netdraw, SIENA and KrackPlot.

\section{Methods}

This article is the result of a research study that uses the network analysis approach to assess regional connectivity in West Kalimantan. As adopted from the Indonesian spatial structure plan, infrastructure is divided into the road, public transportation (land, sea, and air), energy (electricity), telecommunication, water sources, and environment management (water and waste). In this research, we used infrastructure that supports the movement of people. In general, data 
is collected through key infrastructure facilities that connect regions in West Kalimantan, such as highways and public transportation routes (land, sea and air). Each of the connectivity is converted into a node/vertex that represents each region that is connected to another (Fig. 1).

Meanwhile, the spread of COVID-19 is illustrated through a timeline containing data pertaining to each region in West Kalimantan. Next, the existing data and network analysis are superimposed with the spread per region to observe the tendencies of the spread and connectivity as well as to facilitate the discussion that is established. Stages of the study are conducted in the following ways:

1. Data is collected in the form of interconnectivity between regions in West Kalimantan and other regions outside West Kalimantan as long as they connected, which are linked through physical facilities or infrastructure such as (1) road network and (2) land, sea and air transportation network (origin-destination). Besides, the region's characteristics, such as population, are also collected. Data is collected from West Kalimantan's geoportal (http:// geospasial.kalbarprov.go.id/jelajah.html), National Air Traffic Services (https://ap1. co.id/id), Indonesian national shipping (https://www.pelni.co.id/), and Central Bureau of Statistics (https://kalbar.bps.go.id/)

2. Data pertaining to the spread of COVID-19 in West Kalimantan within the timeline is collected from the official data of West Kalimantan province (https://dinkes.kalbarprov.go.id/covid-19/).

3. Data of regional connectivity is converted to nodes/vertices representing the regions and connections between regions linked by physical transportation facilities and infrastructures from (1) roads and (2) land, sea and air transportation facilities

4. Analysis of connectivity through the 'network analysis' approach that analyzes the tendencies of the regions for the measurement of centrality and group or block. Centrality is about the most important actors in a social network (Wasserman \& Faust, 1994), for the measurement, four basic centrality measures are (1) degree, (2) closeness, (3) betweenness, and (4) eigenvector. Each parameter is defined as follows:

- Degree is the number of lines connected to a point (link) (Scott, et al., 2008; Borgatti et al., 2013).

- Closeness reflects how close the actors/ points are to each other. One point becomes central if it can interact quickly with another point (Wasserman \& Faust, 1994).

- Betweenness refers to the actors/points that are in the middle of others, bridging and controlling the flow within a network (Wasserman \& Faust, 1994; Borgatti, Borgatti et al., 2013).

- Eigenvector determines the most central actor/point in terms of the overall
A

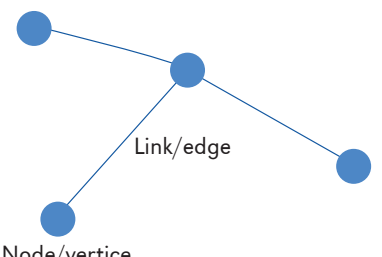

Node/vertice
B

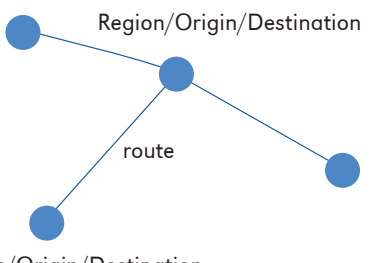

Region/Origin/Destination

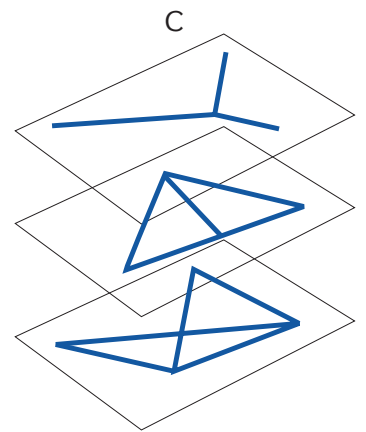

Figure 1. Conversion concept: (A) a basic network, (B) a regional network, (C) a combined network that consists of several networks and calculated concurrently 
network structure (Hanneman \& Riddle, 2005; Borgatti, et al., 2013; Borgatti, 1995).

5. Analysis of connectivity through group or block. The definition of group/block here is several objects or things that are grouped in common or have a similar pattern of relations (general), which can be calculated using structural equivalence approach. In this research, we used a structural equivalence measurement such as CONCOR to partitioning the vertices of graph into similarity classes (block). Continued by Wasserman \& Faust (1994), two actors are structurally equivalent if they have identical ties to and from all other actors in the network. Structural equivalence can calculate using blockmodels or CONCOR.

6. The analysis uses the UCINET software (Borgatti et al., 2002). According to Butts (2008) one of the general tools in network analysis is UCINET, and we chose to use UCINET based on its analytical capabilities, which can be used to analyze the relationship between points or the location.

7. The findings of the analysis are superimposed with the data relating to the spread of COVID-19 in West Kalimantan regions. Tendencies of centrality and regional groups in the spread of COVID-19 in West Kalimantan are also described.

8. Presentation of the findings of tendencies of centrality and block measurement is justified through the discussion of previous research results regarding regions connectivity (transportation), urban hierarchy, and population.

\section{Findings and discussion}

\section{Centrality measurement}

Based on the collected data concerning the main connectivity of cities/Regencies in West Kalimantan through the land, sea and air, a number of connections are obtained, as presented in the table 1 and figure 2 below.

The analysis of connectivity using the network analysis approach in West Kalimantan is undertaken with some measurement details that are in accordance with the research approach used, namely the centrality of a region and the group or block (structural equivalence) of connected regions in West Kalimantan. For centrality measurement, some of the parameters are (1) degree, (2) closeness, (3) betweenness and (4) eigenvector. The findings of the centrality network (connectivity) measurement in West Kalimantan are as follows:

From the findings (Tab. 2), it is evident that Kubu Raya Regency is the region that has the highest scores in each measurement category. The five regions with the highest scores for the degree are Kubu Raya, Pontianak, Sanggau, Sarawak and Sintang; these are the regions that are the most connected to other regions. With respect to the closeness score, Kubu Raya again has the highest score, followed by Sanggau, Sarawak and Sintang. In the interpretation of the findings of closeness, this measurement indicates which region is the fastest one to reach other (close) regions in the existing network configuration. The average betweenness scores of Kubu Raya, Sarawak, Ketapang, Sanggau and Sintang are rather high compared to other regions. It may indicate that these regions have an effective reach when traveling to other regions and become centers (hubs) for other areas. With regard to the eigenvector score of the main area (central), it can be seen that regions such as Kubu Raya, Sarawak, Sintang, Sanggau and Kapuas Hulu are some of the central regions in West Kalimantan's network configuration.

From the results (Tab 2), it can be seen that Kubu Raya Regency, which is adjacent to the provincial capital or Pontianak City, is one of the important or central regions in the network system in West Kalimantan. In the data related to connectivity (Tab. 1), Kubu Raya Regency is seen to have multiple interactions/relations with regions outside West Kalimantan, as Supadio International Airport, which is the main entrance to West Kalimantan from other regions, is located here. In addition, Kubu Raya Regency is adja- 
Table 1. Regional interactions data in West Kalimantan

\begin{tabular}{|c|c|c|c|c|c|c|c|c|}
\hline No & Origin & Destination & No & Origin & Destination & No & Origin & Destination \\
\hline 1 & Pontianak & Kubu Raya & 31 & Nanga Bulik & Ketapang & 61 & Kubu Raya & Yogyakarta \\
\hline 2 & Pontianak & Mempawah & 32 & Sintang & Sanggau & 62 & Kubu Raya & Makassar \\
\hline 3 & Kubu Raya & Sanggau & 33 & Sintang & Sekadau & 63 & Kubu Raya & Sarawak \\
\hline 4 & Kubu Raya & Pontianak & 34 & Sintang & Melawi & 64 & Kubu Raya & Kuala Lumpur \\
\hline 5 & Mempawah & Pontianak & 35 & Sintang & Sarawak & 65 & Kubu Raya & Singapura \\
\hline 6 & Mempawah & Landak & 36 & Sintang & Kapuas Hulu & 66 & Balikpapan & Kubu Raya \\
\hline 7 & Mempawah & Singkawang & 37 & Sekadau & Sanggau & 67 & Bandung & Kubu Raya \\
\hline 8 & Mempawah & Bengkayang & 38 & Sekadau & Sintang & 68 & Banjarmasin & Kubu Raya \\
\hline 9 & Singkawang & Mempawah & 39 & Melawi & Sintang & 69 & Batam & Kubu Raya \\
\hline 10 & Singkawang & Bengkayang & 40 & Kapuas Hulu & Sintang & 70 & Deli Serdang & Kubu Raya \\
\hline 11 & Singkawang & Sambas & 41 & Kapuas Hulu & Sarawak & 71 & Jakarta & Kubu Raya \\
\hline 12 & Landak & Mempawah & 42 & Sarawak & Sambas & 72 & Ketapang & Kubu Raya \\
\hline 13 & Landak & Bengkayang & 43 & Sarawak & Bengkayang & 73 & Kapuas Hulu & Kubu Raya \\
\hline 14 & Landak & Sanggau & 44 & Sarawak & Sanggau & 74 & Pangkalan Bun & Kubu Raya \\
\hline 15 & Bengkayang & Landak & 45 & Sarawak & Sintang & 75 & Sintang & Kubu Raya \\
\hline 16 & Bengkayang & Mempawah & 46 & Sarawak & Kapuas Hulu & 76 & Semarang & Kubu Raya \\
\hline 17 & Bengkayang & Singkawang & 47 & Ketapang & Kayong Utara & 77 & Surabaya & Kubu Raya \\
\hline 18 & Bengkayang & Sambas & 48 & Kayong Utara & Ketapang & 78 & Yogyakarta & Kubu Raya \\
\hline 19 & Bengkayang & Sarawak & 49 & Kubu Raya & Balikpapan & 79 & Makassar & Kubu Raya \\
\hline 20 & Sambas & Singkawang & 50 & Kubu Raya & Bandung & 80 & Sarawak & Kubu Raya \\
\hline 21 & Sambas & Bengkayang & 51 & Kubu Raya & Banjarmasin & 81 & Kuala Lumpur & Kubu Raya \\
\hline 22 & Sambas & Sarawak & 52 & Kubu Raya & Batam & 82 & Singapura & Kubu Raya \\
\hline 23 & Sanggau & Sintang & 53 & Kubu Raya & Deli Serdang & 83 & Serasan & Pontianak \\
\hline 24 & Sanggau & Landak & 54 & Kubu Raya & Jakarta & 84 & Pontianak & Surabaya \\
\hline 25 & Sanggau & Kubu Raya & 55 & Kubu Raya & Ketapang & 85 & Pontianak & Serasan \\
\hline 26 & Sanggau & Sekadau & 56 & Kubu Raya & Kapuas Hulu & 86 & Surabaya & Pontianak \\
\hline 27 & Sanggau & Sarawak & 57 & Kubu Raya & Pangkalan Bun & 87 & Tanjung Pandan & Pontianak \\
\hline 28 & Sanggau & Ketapang & 58 & Kubu Raya & Sintang & 88 & Pontianak & Semarang \\
\hline 29 & Ketapang & Sanggau & 59 & Kubu Raya & Semarang & 89 & Pontianak & Tanjung Pandan \\
\hline 30 & Ketapang & Nanga Bulik & 60 & Kubu Raya & Surabaya & 90 & Semarang & Pontianak \\
\hline
\end{tabular}

Source: West Kalimantan Geoportal; National Air Traffic Company; Services Indonesian Shipping Company, accessed in 2020 .

cent to Pontianak City, which is only $50 \mathrm{~km}$ away from the city center. Therefore, Kubu Raya often becomes one of Pontianak City's supporting regions. Development in Kubu Raya tends to support development in Pontianak City as well. Furthermore, Pontianak City is also a national activity center with transport nodes that facilitate international, national and provincial activities, such as export and import as well as industrial and service activities. Thus, international and national scale activities eventually end up in Pontianak following a transit through the gateway, which is Kubu Raya due to its international airport.

Sintang and Sanggau Regencies are also rather central in the configuration of connectivity networks in West Kalimantan, managing to attain significant scores in each measurement category. They are geographically situated in the middle area of West Kalimantan Province, linking the western and eastern as well as the northern and southern regions up to the border areas that are directly 


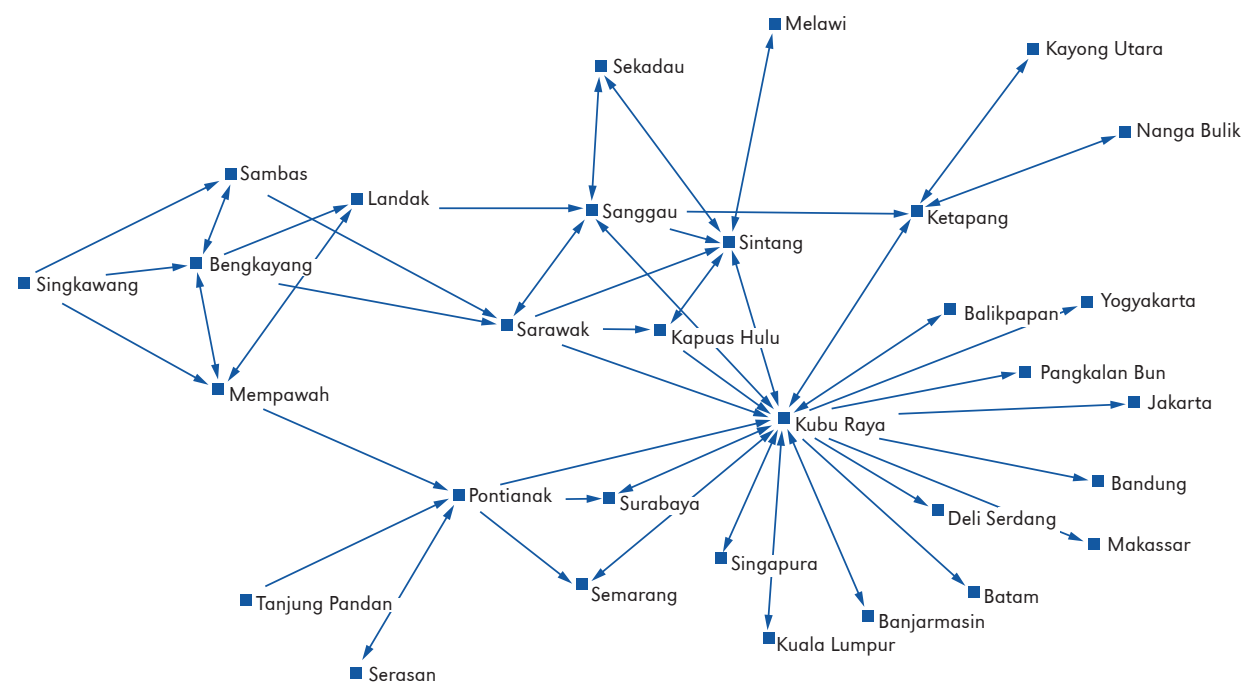

Figure 2. Connectivity network in West Kalimantan

adjacent to Sarawak, Malaysia. In addition, these Regencies have borders (in the northern part) that enable direct access to Sarawak that resides in a neighboring country. There are at least five Regencies in West Kalimantan that are adjacent to and can be accessed directly from Sarawak. Therefore, Sarawak is also one of the regions outside of West Kalimantan that have a significant centrality level in West Kalimantan due to its proximity/ease of access.

\section{Block measurement}

The block measurement uses the CONvergence of the iterated CORrelations (CONCOR) approach. This approach is carried out by dividing data to separate blocks through the convergence of iterated correlations within the UCINET analysis network (Hanneman \& Riddle, 2005). CONCOR is conducted by connecting each pair of actors. Each row of these actors' correlation matrix is then extracted and correlated with each other. This approach looks for how alike the similarity vector of actor $X$ and that of actor $Y$ are. This process is undertaken repeatedly until elements in the 'repeating correlation matrix' finally meet at the value of +1 or -1 .
The obtained findings in the measurement process performed in UCINET are described in Figure 3 below.

Based on the measurement or simulation conducted with UCINET (Fig. 3 and Tab. 3), it is clear that there are at least eight blocks or groups that are formed and interconnected (vertically and horizontally). These blocks indicate proximity or equivalence of each region that closely interacts with another. In Figure 3, we can see the block partition. Eight blocks consist of several regions, where each block is also interconnected with other blocks. Block analysis is more emphasized on the relationship between blocks (which have several regions) with other blocks (which also have several regions in it). To explain Figure 3, we can see the score in Table 3, that there are relationships between blocks (for example, block 4 with block 1, and vice versa) that have a maximum closeness score (score 1.000). Each region interacts with other regions that are equivalent (from CONCOR's perspective) to form the overall network. It is evident from Figure 3 and Table 3 that the blocks that are closely connected are blocks 1, 2, 3 and 4, each interaction having a maximum density matrix score of 1.000 . This indicates that each of these blocks 
Table 2. Centrality measurement in West Kalimantan

\begin{tabular}{|c|c|c|c|c|c|}
\hline No & Cities/Regencies & Degree & Closeness & Betweenness & Eigenvector \\
\hline 1 & Balikpapan & 3.333 & 42.254 & 0.000 & 15.708 \\
\hline 2 & Bandung & 3.333 & 42.254 & 0.000 & 15.708 \\
\hline 3 & Banjarmasin & 3.333 & 42.254 & 0.000 & 15.708 \\
\hline 4 & Batam & 3.333 & 42.254 & 0.000 & 15.708 \\
\hline 5 & Bengkayang & 16.667 & 38.961 & 3.265 & 17.814 \\
\hline 6 & Deli Serdang & 3.333 & 42.254 & 0.000 & 15.708 \\
\hline 7 & Jakarta & 3.333 & 42.254 & 0.000 & 15.708 \\
\hline 8 & Kapuas Hulu & 10.000 & 46.875 & 0.000 & 32.407 \\
\hline 9 & Kayong Utara & 3.333 & 32.258 & 0.000 & 4.920 \\
\hline 10 & Ketapang & 13.333 & 46.875 & 13.103 & 25.811 \\
\hline 11 & Kuala Lumpur & 3.333 & 42.254 & 0.000 & 15.708 \\
\hline 12 & Kubu Raya & 63.333 & 71.429 & 75.640 & 82.403 \\
\hline 13 & Landak & 10.000 & 39.474 & 1.768 & 14.119 \\
\hline 14 & Makassar & 3.333 & 42.254 & 0.000 & 15.708 \\
\hline 15 & Melawi & 3.333 & 33.708 & 0.000 & 8.249 \\
\hline 16 & Mempawah & 13.333 & 38.961 & 4.776 & 13.096 \\
\hline 17 & Nanga Bulik & 3.333 & 32.258 & 0.000 & 4.920 \\
\hline 18 & Pangkalan Bun & 3.333 & 42.254 & 0.000 & 15.708 \\
\hline 19 & Pontianak & 20.000 & 50.847 & 18.987 & 28.308 \\
\hline 20 & Sambas & 10.000 & 36.585 & 1.710 & 13.457 \\
\hline 21 & Sanggau & 20.000 & 52.632 & 10.796 & 43.159 \\
\hline 22 & Sarawak & 20.000 & 51.724 & 13.344 & 44.323 \\
\hline 23 & Sekadau & 6.667 & 36.145 & 0.000 & 16.477 \\
\hline 24 & Semarang & 6.667 & 45.455 & 0.000 & 21.104 \\
\hline 25 & Serasan & 3.333 & 34.091 & 0.000 & 5.396 \\
\hline 26 & Singapura & 3.333 & 42.254 & 0.000 & 15.708 \\
\hline 27 & Singkawang & 10.000 & 30.303 & 0.345 & 8.458 \\
\hline 28 & Sintang & 20.000 & 50.000 & 9.368 & 43.275 \\
\hline 29 & Surabaya & 6.667 & 45.455 & 0.000 & 21.104 \\
\hline 30 & Tanjung Pandan & 3.333 & 34.091 & 0.000 & 5.396 \\
\hline 31 & Yogyakarta & 3.333 & 42.254 & 0.000 & 15.708 \\
\hline
\end{tabular}

${ }^{*}$ In bold: regions with highest scores

Source: UCINET analysis result, 2020.

are interacting with each other more closely than other blocks.

If observed in a more detailed manner, Kubu Raya appears as a Regency (region) that has its own group members and the one which interacts the most with other blocks, especially with blocks 1, 2 and 3, and vice versa, with each having a density matrix score of 1 . Block 1 is generally composed of regions outside West Kalimantan; only Ketapang is within West Kalimantan. Block 2 contains regions such as Pontianak City, Semarang and Surabaya, which tend to be connected through a sea route or port. Block 3 contains Sintang, Kapuas Hulu, Sarawak and Sanggau, regions in the eastern area of West Kalimantan, which are directly connected by road. Overall, it can be observed that Kubu Raya (block 4) tends to be closely connected with the other blocks in West Kalimantan, especially the one outside (block 1), Pontianak block (block 2) and the block of the eastern 
Relation 1

Blocked Matrix

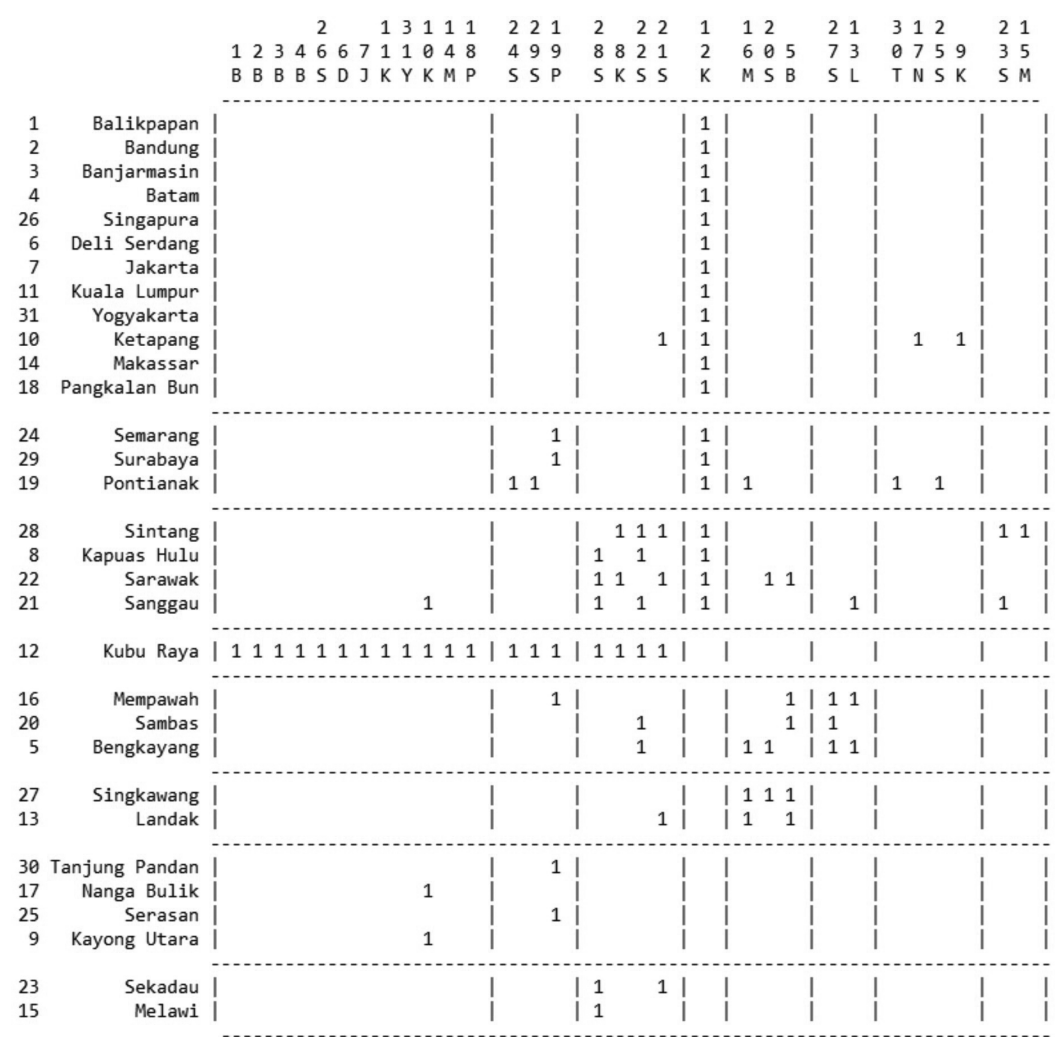

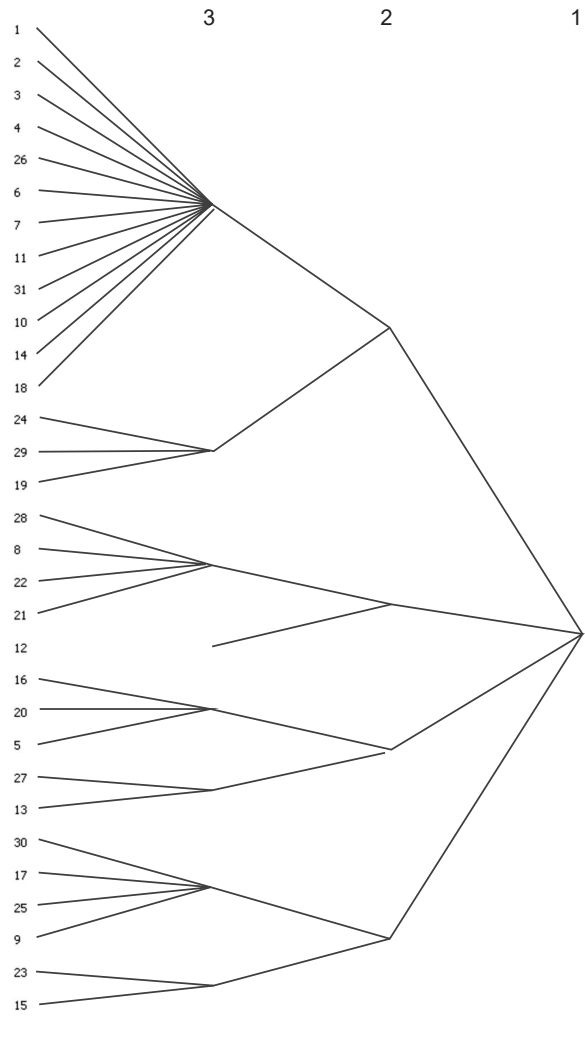

Figure 3. CONCOR measurement in West Kalimantan

Source: UCINET analysis result, 2020. 
side of West Kalimantan (block 3). Kubu Raya has an important role as a region that stands alone and is connected to three other blocks that have various interconnected regions within them. The conclusion is that the regions in West Kalimantan that are connected with respect to the highest density score within a block are Kubu Raya, Ketapang, Pontianak, Sintang, Kapuas Hulu and Sanggau (Fig. 4, right). Additionally, there are areas outside West Kalimantan that are connected through transportation infrastructures.

\section{Discussion: The spread of COVID-19 and regional connectivity in West Kalimantan}

It can be summarized from the West Kalimantan Health Office data (https://dinkes.kalbarprov. go.id/covid-19/) that certain cities/Regencies have an increasing occurrence of confirmed patients, suspects or close contacts. This statement is supported by the data in the table below (Tab. 4). Cities/Regencies such as Pontianak, Kubu Raya and Ketapang consistently have the highest number of confirmed cases.

Table 3. CONCOR measurement in West Kalimantan

\begin{tabular}{|c|c|c|c|c|c|c|c|c|}
\hline Block & 1 & 2 & 3 & 4 & 5 & 6 & 7 & 8 \\
\hline 1 & 0.000 & 0.000 & 0.021 & 1.000 & 0.000 & 0.000 & 0.042 & 0.000 \\
2 & 0.000 & 0.667 & 0.000 & 1.000 & 0.111 & 0.000 & 0.167 & 0.000 \\
3 & 0.021 & 0.000 & 0.833 & 1.000 & 0.167 & 0.125 & 0.000 & 0.375 \\
4 & 1.000 & 1.000 & 1.000 & & 0.000 & 0.000 & 0.000 & 0.000 \\
5 & 0.000 & 0.111 & 0.167 & 0.000 & 0.667 & 0.833 & 0.000 & 0.000 \\
6 & 0.000 & 0.000 & 0.125 & 0.000 & 0.833 & 0.000 & 0.000 & 0.000 \\
7 & 0.042 & 0.167 & 0.000 & 0.000 & 0.000 & 0.000 & 0.000 & 0.000 \\
8 & 0.000 & 0.000 & 0.375 & 0.000 & 0.000 & 0.000 & 0.000 & 0.000 \\
\hline
\end{tabular}

*In bold: regions with highest scores Source: UCINET analysis result, 2020.

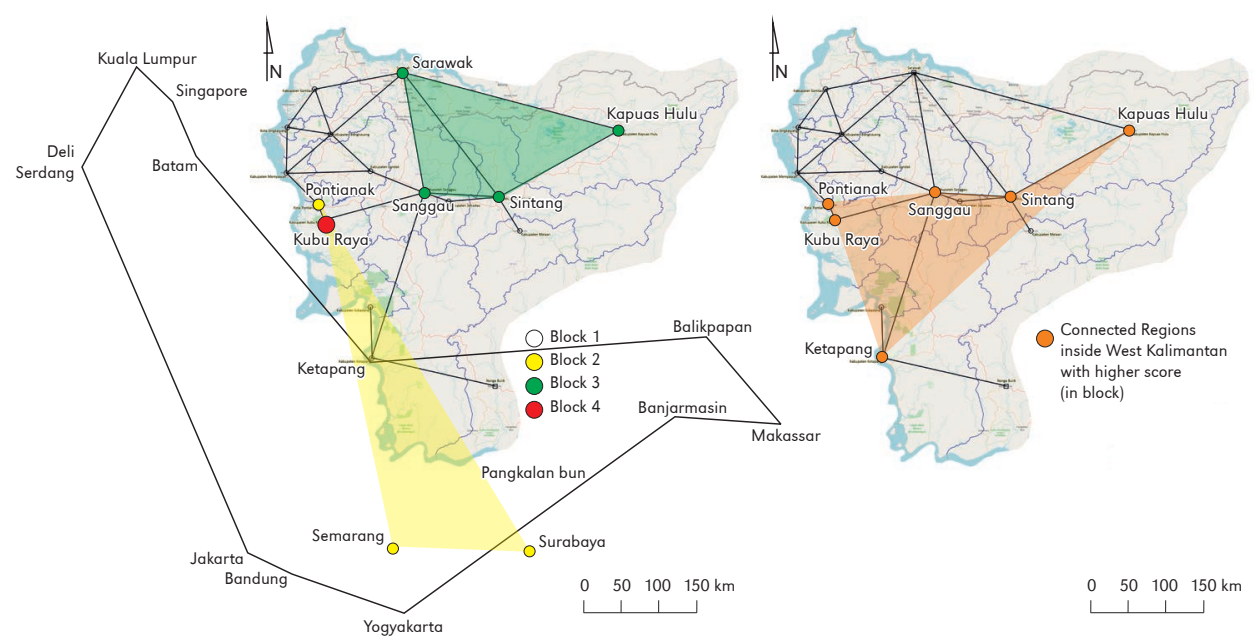

Figure 4. Block in West Kalimantan

Source: UCINET analysis result, 2020. 
Table 4. COVID-19 cases in West Kalimantan

\begin{tabular}{|c|c|c|c|c|c|c|c|c|c|c|c|c|c|}
\hline \multirow{3}{*}{ No } & \multirow{3}{*}{$\begin{array}{l}\text { Cities/ } \\
\text { regencies }\end{array}$} & \multicolumn{12}{|c|}{ COVID-19 cases in West Kalimantan } \\
\hline & & \multicolumn{3}{|c|}{24 August 2020} & \multicolumn{3}{|c|}{1 September 2020} & \multicolumn{3}{|c|}{7 September 2020} & \multicolumn{3}{|c|}{15 September 2020} \\
\hline & & C & $\mathrm{s}$ & CC & C & $\mathrm{s}$ & CC & C & $\mathrm{s}$ & CC & C & s & CC \\
\hline 1 & Pontianak & 155 & 234 & 895 & 170 & 155 & 234 & 895 & 170 & 155 & 234 & 895 & 170 \\
\hline 2 & Singkawang & 12 & 30 & 691 & 13 & 12 & 30 & 691 & 13 & 12 & 30 & 691 & 13 \\
\hline 3 & Mempawah & 20 & 32 & 284 & 22 & 20 & 32 & 284 & 22 & 20 & 32 & 284 & 22 \\
\hline 4 & Bengkayang & 7 & 25 & 2,340 & 14 & 7 & 25 & 2,340 & 14 & 7 & 25 & 2,340 & 14 \\
\hline 5 & Sambas & 20 & 48 & 3,840 & 22 & 20 & 48 & 3,840 & 22 & 20 & 48 & 3,840 & 22 \\
\hline 6 & Landak & 46 & 35 & 1,480 & 55 & 46 & 35 & 1,480 & 55 & 46 & 35 & 1,480 & 55 \\
\hline 7 & Sanggau & 25 & 19 & 811 & 25 & 25 & 19 & 811 & 25 & 25 & 19 & 811 & 25 \\
\hline 8 & Kubu Raya & 93 & 90 & 302 & 94 & 93 & 90 & 302 & 94 & 93 & 90 & 302 & 94 \\
\hline 9 & $\begin{array}{l}\text { Kayong } \\
\text { Utara }\end{array}$ & 3 & 9 & 201 & 3 & 3 & 9 & 201 & 3 & 3 & 9 & 201 & 3 \\
\hline 10 & Ketapang & 82 & 20 & 2,184 & 87 & 82 & 20 & 2,184 & 87 & 82 & 20 & 2,184 & 87 \\
\hline 11 & Sekadau & 7 & 8 & 1,331 & 7 & 7 & 8 & 1,331 & 7 & 7 & 8 & 1,331 & 7 \\
\hline 12 & Melawi & 30 & 5 & 228 & 30 & 30 & 5 & 228 & 30 & 30 & 5 & 228 & 30 \\
\hline 13 & Sintang & 29 & 2 & 770 & 41 & 29 & 2 & 770 & 41 & 29 & 2 & 770 & 41 \\
\hline \multirow[t]{2}{*}{14} & Kapuas Hulu & 13 & 17 & 687 & 38 & 13 & 17 & 687 & 38 & 13 & 17 & 687 & 38 \\
\hline & Total & 542 & 574 & 16,044 & 621 & 542 & 574 & 16,044 & 621 & 542 & 574 & 16,044 & 621 \\
\hline
\end{tabular}

Note: $\mathrm{C}=$ confirm cases; $\mathrm{S}=$ suspect; $\mathrm{CC}$ : close contact

${ }^{\star}$ In bold: regions with highest scores

Source: UCINET analysis result, 2020.

Pontianak, Kubu Raya and Sambas have the highest number of suspects. The regions with the highest number of close contact cases are Sambas, Bengkayang and Kepatang.

Based on the findings above, First, if superimposed, the data relating to the spread of COVID-19 in West Kalimantan (Tab. 4) show that Kubu Raya and Pontianak have the highest number of confirmed cases and suspects in West Kalimantan. When superimposed with the measurement of centrality and block undertaken previously, it becomes evident that these two regions are the main areas in the network configuration and connectivity in West Kalimantan. Kubu Raya itself has high scores in all categories in the centrality measurement. Pontianak too tends to have high centrality scores along with Sanggau, Sintang and Kapuas Hulu. Cities/ Regencies in West Kalimantan such as Pontianak, Kubu Raya, Katapang, Sanggau, Sintang and Kapuas Hulu are seen to be interconnected regions in blocks that have the highest scores in CONCOR's measurement. Moreover, Pontianak, Kubu Raya and Ketapang are the three regions that have the highest number of confirmed cases. Pontianak, Kubu Raya and Sambas have the highest number of suspects. The three regions with the highest number of close contacts are Sambas, Bengkayang and Ketapang (Fig. 5).

Referring to the recapitulation of the data of regions with the highest scores (Tab. 5), it is evident that Kubu Raya and Pontianak are the two regions that have the highest cases of COVID-19, high centrality scores and are connected in each of their blocks. Moreover, Kubu Raya and Pontianak tend to be the two entrances to West Kalimantan and the main areas for connectivity and distribution to other regions. Pontianak, in particular, is a provincial capital, meaning that most of the people in West Kalimantan are in Pontianak. It is also a transit location from Kubu Raya (which has 


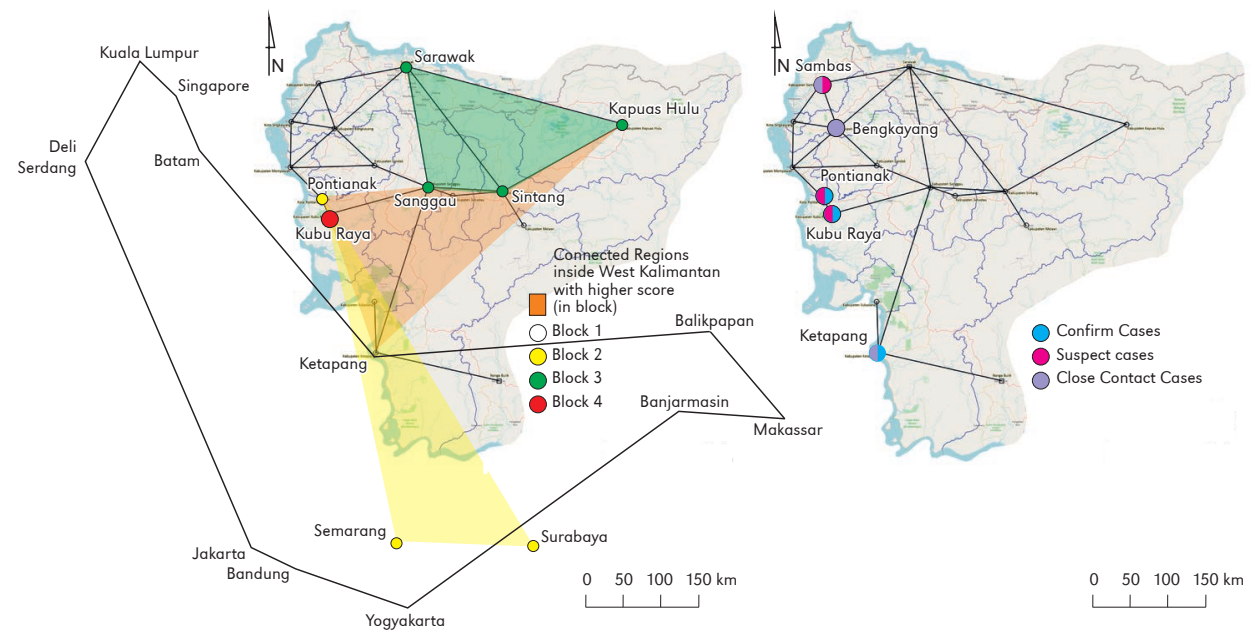

Figure 5. Block and COVID-19 cases in West Kalimantan

Source: UCINET analysis result, 2020.

an international airport). Meanwhile, Kubu Raya is the main entrance of the air transport route in West Kalimantan and the hub that connects Pontianak to the eastern areas of West Kalimantan (Sanggau, Sintang, and Kapuas Hulu) and its southern areas (Kayong Utara, Ketapang).

Second, with respect to connectivity (centrality and block measurement) and the spread of COVID-19 in West Kalimantan, several regions that have significant scores can be seen in the table below (Tab. 5). It is evident from the table that regions such as Pontianak and Kubu Raya have significant scores in centrality, are interconnected in a block and have a rather high number of COVID-19 cases. These two areas included in each category in three measurements: centrality, block, and the number of COVID-19 cases (Tab. 5). As regards the connectivity aspect of both regions, Kubu Raya has the main entrance for air transport, which is the Supadio International Airport. The air transportation network is connected to other regions in West Kalimantan such as Sintang, Kapuas Hulu and Ketapang. These three regions also have significant scores in the measurement (Tab. 5). In addition to Kubu Raya, one of the regions that have significant scores in each measurement (Tab. 5) is Pontianak. Pontianak is the provincial capital of West Kalimantan with a population of 600,000 . It is in Pontianak that the Dwikora Port and other pioneer ports are located; these are the main entrances facilitating transport via sea route in West Kalimantan. This sea route is traversed by freight ships and passenger ships. As a provincial capital, Pontianak is a city of trade and services, where there are several supporting facilities. With respect to connectivity, Pontianak is directly connected to Kubu Raya, which is the location of an international airport (Supadio). Moreover, according to the public transportation information at Supadio Airport, Pontianak happens to be the main destination. The transit of settlers from Kubu Raya tends to be Pontianak, which has adequate facilities for accommodation and further transport. Administratively, Pontianak is directly adjacent to only two regions, namely Kubu Raya and Mempawah.

In the perspective of transportation connectivity, both Tuncer and Le (2014) and Grais et al. (2003) stated that the spread of a pandemic can be hastened by the acceleration of interconnectivity between regions and cities through (air) transport. They further stated that if cities or regions are connected, changes 
Table 5. The measurement comparison

\begin{tabular}{|c|c|c|c|c|c|c|c|c|c|c|}
\hline \multicolumn{5}{|c|}{$\begin{array}{l}\text { Cities/ regencies with significant } \\
\text { score of centrality }\end{array}$} & \multicolumn{2}{|c|}{$\begin{array}{l}\text { Connected cities/ } \\
\text { regencies (in block) }\end{array}$} & \multicolumn{4}{|c|}{$\begin{array}{l}\text { Cities/ regencies with significant } \\
\text { number of COVID-19 cases }\end{array}$} \\
\hline \multirow[b]{2}{*}{$\begin{array}{l}\text { Cities/ } \\
\text { regencies }\end{array}$} & \multicolumn{4}{|c|}{ score } & \multirow[b]{2}{*}{$\begin{array}{l}\text { cities/ } \\
\text { regencies }\end{array}$} & \multirow[b]{2}{*}{$\begin{array}{l}\text { block } \\
\text { score }\end{array}$} & \multirow[b]{2}{*}{$\begin{array}{l}\text { cities/ } \\
\text { regencies }\end{array}$} & \multirow[b]{2}{*}{ C } & \multirow[b]{2}{*}{ s } & \multirow[b]{2}{*}{$\mathrm{CC}$} \\
\hline & 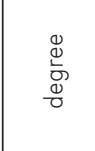 & 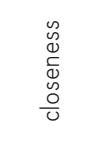 & 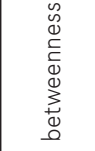 & 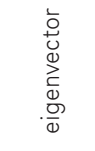 & & & & & & \\
\hline Kubu Raya & 63.333 & 71.429 & 75.640 & 82.403 & $\begin{array}{l}\text { Pontianak } \\
\text { (block 2) }\end{array}$ & 1.000 & Pontianak & 155 & 234 & 895 \\
\hline Sanggau & 20.000 & 52.632 & 10.796 & 43.159 & $\begin{array}{l}\text { Sintang } \\
\text { (block 3) }\end{array}$ & 1.000 & Kubu Raya & 93 & 90 & 302 \\
\hline Sintang & 20.000 & 50.000 & 9.368 & 43.275 & $\begin{array}{l}\text { Kapuas Hulu } \\
\text { (block 3) }\end{array}$ & 1.000 & Ketapang & 82 & 20 & 2184 \\
\hline Pontianak & 20.000 & 50.847 & 18.987 & 28.308 & $\begin{array}{l}\text { Sanggau } \\
\text { (block 3) }\end{array}$ & 1.000 & Sambas & 20 & 48 & 3840 \\
\hline Kapuas Hulu & 10.000 & 46.875 & 0.000 & 32.407 & $\begin{array}{l}\text { Kubu Raya } \\
\text { (block 4) }\end{array}$ & 1.000 & Bengkayang & 7 & 25 & 2340 \\
\hline Ketapang & 13.333 & 46.875 & 13.103 & 25.811 & & & & & & \\
\hline Sarawak & 20.000 & 51.724 & 13.344 & 44.323 & & & & & & \\
\hline
\end{tabular}

Note: $\mathrm{C}=$ Confirm cases; $\mathrm{S}=$ Suspect; CC: Close Contact

${ }^{\star}$ In bold: regions with highest scores

Source: UCINET analysis result, 2020.

in reproduction of the spread between initial regions and destination regions can become more effective. If we see from the origin COVID-19, there are similarities in the position of the regions in terms of the transportation hub. A spread of COVID-19 from Wuhan was particulary given as the position of Wuhan as a central hub in China's rail and aviation networks. The population flow from Wuhan to other areas fundamentally determines the eventual distribution of total infections and demonstrated its potential to generate explosive outbreak in China (Jia et al, 2020; Tian et al. 2020). In other case, according to Baker et al. (2020), the COVID-19 in New Zealand transmission because of large number of visitors who came to New Zealand, such as tourist and student who arrive in the country, predominantly form Europe and mainland China. While in Singapore, there are an imported cases or infection from external sources in case Singapore as a travel hub (Lee et al, 2020). And somehow, the transmission exposure risk happen before boarding the air-craft at the airport (Schwatrz et al et al, 2020). From several related studies, the ease of connectivity between several regions can support the spread of disease, as well as conditions in West Kalimantan

Third, Kubu Raya is connected to Sanggau by overland road, which continues to Sintang, Kapuas Hulu and Ketapang, where the regions also many confirmed cases. As the location of an international airport, Kubu Raya is the main region that is connected to other areas outside West Kalimantan. Administratively, Kubu Raya is directly adjacent to Pontianak, Mempawah, Landak, Sanggau, Ketapang and Kayong Utara. In addition, the distance between the international airport in Kubu Raya and Pontianak (the provincial capital) is relatively small; it is less than $20 \mathrm{~km}$ and can be covered in just $1 / 2$ hour. According to Valleron et al. (2010), the hypotheses that may be developed regarding the spread of a virus concern not only the amount of travel or transport between the regions but also the connectivity between them and 
their connecting facilities. Followed by Dunn and Atlanta (1957), transportation is a major factor in the spread of diseases. Moreover, a dense population that spreads to neighboring regions is also among the estimated factors contributing to the spread of disease.

In the network and connectivity configuration, as indicated by the Regional Spatial Planning Scheme, Pontianak is an order 1 city within the system of cities in West Kalimantan Province. It functions as a National Activity Center (PKN). Thus, Pontianak becomes a gateway to international areas (especially ASEAN) and is a driving force for its surrounding areas. As a national activity center, Pontianak functions as the center of trade and services as well as the entrance and exit point for goods and people traversing the West Kalimantan province. Consequently, Pontianak is one of the main areas for the movement of goods and services in West Kalimantan, supported by its close proximity to the international airport and the port, as well as its provision of sufficient facilities and the required infrastructure. Pontianak, as the provincial capital and a large city, has a large number of residents and is 'high' in the urban hierarchy. In Table 6, we can see that Pontianak and Kubu Raya are two regions with a higher number of populations.

In the perspective of population density in connecting urban area, according to Bherwani et al. (2020), the eviden that there is a significant relationship between number of population and COVID-19. In the study of Inaida et al. (2011), the spread of a disease (endemic) is shown to occur faster in metropolitan areas or regions with large or dense populations, resulted from direct infection from person to person. Moreover, Merler and Ajelli (2009) also stated that spatial and populational configurations have an impact on the spread of a disease. Urban hierarchy tends to determine the spread. For example, a large city can pass an infection to a small city. From other research results, several Authors has mentioned about the relationship between population in urban areas. According to Peng et al. (2020), the epidemic outbreak areas were founded in high-density residential areas, representing the entering stage of community transmission. Followed CDC COVID-19 Response Team (2020) said COVID-19 is primarily transmitted by respiratory droplets, population density might also play a significant role in the acceleration of transmission. Related to urban areas, summarized by Chang et al. (2020), epidemic disease typically develops into two stages, initially affecting the more densely populated urban areas, and then spreading to regional and rural areas. While cases in England and Wales shown that the epidemic spread reaching urhan areas first followed by rural areas.(Danon et al, 2020). The connected transportation network, high population (as a big city), and the urban hierarchy can also support disease spread, as the several related literatures lead to. In West Kalimantan itself as a case study, two regions such as Kubu Raya and Pontianak are two central regions with a high position in urban hierarchy, which connected each other with a large population. Our findings lead to regions with those characteristics can be susceptible to the spread of disease and can spread it.

Table 6. Population in West Kalimantan

\begin{tabular}{|r|l|c|c|}
\hline No. & $\begin{array}{c}\text { Cities/ } \\
\text { regencies }\end{array}$ & $\begin{array}{c}\text { Number } \\
\text { of population } \\
(2019)\end{array}$ & $\begin{array}{c}\text { Annual } \\
\text { growth [\%] } \\
(2020-2019)\end{array}$ \\
\hline 1 & Pontianak & $\mathbf{6 4 6 , 6 6 1}$ & 1.68 \\
2 & Singkawang & 222,910 & 1.96 \\
3 & Mempawah & 264,225 & 1.32 \\
4 & Bengkayang & 255,261 & 1.87 \\
5 & Sambas & 535,725 & 0.82 \\
6 & Landak & 377,305 & 1.48 \\
7 & Sanggau & 470,224 & 1.54 \\
8 & Kubu Raya & $\mathbf{5 7 9 , 3 3 1}$ & 1.59 \\
9 & Kayong Utara & 112,715 & 1.80 \\
10 & Ketapang & 512,783 & 2.00 \\
11 & Sekadau & 201,578 & 1.13 \\
12 & Melawi & 208,417 & 1.68 \\
13 & Sintang & 418,785 & 1.51 \\
14 & Kapuas Hulu & 263,207 & 1.86 \\
\hline
\end{tabular}

*In bold: regions with highest scores

Source: Central Bureau of Statistics, 2020 
Fourth and the last, the hypothesis based on the data and superimposition is that regions that have a higher centrality scores and multiple connections between their blocks tend to have a higher number of COVID-19 cases compared to other regions. This is also supported by the role of each region as the main gateway to West Kalimantan and as a hub to the other regions. In addition, the role of each region in urban hierarchy, the number of residents and the proximity between one another also tend to affect the spread of COVID-19 in West Kalimantan. The connection between Kubu Raya dan Pontianak as the regions with a higher number of COVID-19 can be inferred that a transportation network that tends to be quite easy to take from Kubu Raya as the main entrance to West Kalimantan could be one of the reasons that Kubu Raya and Pontianak tend to have the highest number of COVID-19 cases. The regions that act as gateways and hubs in West Kalimantan tend to be the central regions with the most confirmed cases from the descriptions above. At the policy level, to controlling the spread of an infectious disease from a network perspective, one can consider the concept of 'cut links' or reducing the degree of connectivity. Suppose a 'shortcut' approach is used to improve connectivity (inside Hsu \& Shih, 2008). In that case, we can use the 'reverse' concept of shortcut to preventing the spread of disease from a network perspective, including:

1. Extend separation: providing the connectivity inter-regions by extend the distance between neighbors;

2. Increase steps and time required by any kind of communication between nodes;

3. Reduce network interaction by introduce few nodes in-between;

4. Develop multi modal system (Keijer \& Rietveld in Nijkamp et al., 2000);

5. Considering two/more hubs sharing with different advantages value and needs (Li et al., 2012), and;

6. Area upgrade and broadened the connecting (Lee, 1998).

\section{Conclusion}

The spread of an infection (endemic/pandemic) can be caused by several factors, one of them being the movement and connectivity between regions. Connected regions facilitate the mobility of humans, materials or information. Such connectivity may affect the spread of infection and make it faster/ more effective. From the findings that have been gathered, it is evident that regions like Kubu Raya and Pontianak have a high number of COVID-19 cases, especially confirmed ones. After these two regions, Ketapang has the highest number of confirmed cases. Considering their centrality and block measurements, Kubu Raya and Pontianak are 'featured' as regions with the highest score. When regarded from the context of regional connectivity, both of them are the main 'gateways' to West Kalimantan and 'hubs' directing to other regions in West Kalimantan. Additionally, the role of each region in urban hierarchy, the number of residents and their proximity to one another also tend to affect the spread of COVID-19 in West Kalimantan.

Findings that can be highlighted in this study, and which contribute to science discourse are: (1) two adjacent regions (in block) can be one of the transmission factors, (2) regions with central positions and transportation hubs can be the primary source of distribution, (3) regions with a large number of population and play as 'a key areas' in urban hierarchies tend to have high confirmed cases, and (4) another interesting finding is some regions with low centrality score have a relatively high number of COVID-19 Close Contacts cases than regions with a high centrality/block score. These regions are like Sambas, Bengkayang, Landak, and Sekadau. Where these regions tend to have a dense population and some regions like Sambas and Bengkayang are directly related to Sarawak Malaysia.

This study's limitation is the number of cases used referring to the data for the last one month. In its progress, confirmed cases will continue to fluctuate and may change in the 
following months. From the perspective of network analysis, the analysis is only performed by calculating centrality and block. The analysis is carried out only by looking at the number of regions that interact with other regions (node-to-node) without considering certain weights or attributes in the interaction between the regions, such as distance, frequency of trips, types of interactions, and so on. For those reasons, further research can be carried out with more comprehensive data and analysis. Besides, researchers can also carry out further research to find what factors affect some regions with low centrality score in having a significant number of COVID-19 Close Contacts cases.

\section{Acknowledgements}

We thank Ministry of Research, Technology, and Higher Education of the Republic of Indonesia (Kemenristekdikti - Kemenristek/BRIN) for financial support of the research through multi-year basic research scheme (re-focusing COVID-19).

Editors' note:

Unless otherwise stated, the sources of tables and figures are the authors', on the basis of their own research.

\section{References}

Asadi, S., Bouvier, N., Wexler, A.S., \& Ristenpart, W.D. (2020). The coronavirus pandemic and aerosols: Does COVID-19 transmit via expiratory particles? Aerosol Science and Technology, 54(6), 635-638. https://doi.org/10.1080/02786826.2020.1749229

Bajardi, P., Poletto, C., Ramasco, J.J., Tizzoni, M., Colizza, V., \& Vespignani, A. (2011). Human mobility networks, travel restrictions, and the global spread of 2009 H1N1 pandemic. PLOS ONE, 6(1). https://doi.org/10.1371/journal.pone.0016591

Baker, M.G., Wilson, N., \& Anglemyer, A. (2020). Successful Elimination of COVID-19 Transmission in New Zealand. The New England journal of medicine, 383(8), e56. https://doi.org/10.1056/NEJMc2025203

Bherwani, H., Anjum, S., Kumar, S., Gautam, S., Gupta, A., Kumbhare, H., Anshul, A., \& Kumar, R. (2020). Understanding COVID-19 transmission through Bayesian probabilistic modeling and GIS-based Voronoi approach: a policy perspective. Environment, Development and Sustainability, 23, 5846-5864. https://doi.org/10.1007/s10668-020-00849-0

Borgatti, S.P., Everett, M.G., Johnson, J.C. (2013). Analyzing social networks. Sage Publications

Borgatti, S, P., Everett, M, G., Freeman, L, C. (2002). UCINET for Windows: Software for Social Network Analysis. Harvard, Analytic Technologies

Borgatti, S, P. (1995). Centrality and AIDS. Connections 18 (1), 112-115.

Butts, C.T. (2008). Social network analysis with sna. Journal of Statistical Software, 24(6). https://doi.org/10.18637/jss.v024.i06

CDC COVID-19 Response Team. (2020). Geographic differences in COVID-19 cases, deaths, and incidence - United States, February 12-April 7, 2020. Morbidity and Mortality Weekly Report, 69(15), 465-471.

Central Bureau of Statistics. (2020). Kalbar Dalam Angka. https://kalbar.bps.go.id/

Chan, J.F.W., Yuan, S., Kok, K.H., To, K.K.W., Chu, H., Yang, J., Xing, F., Liu, J., Yip, C.C.Y., Poon, R.W.S., Tsoi, H.W., Lo, S.K.F., Chan, K.H., Poon, V.K.M., Chan, W.M., Ip, J.D., Cai, J.P., Cheng, V.C.C., Chen, H., ... Yuen, K.Y. (2020). A familial cluster of pneumonia associated with the 2019 novel coronavirus indicating person-to-person transmission: a study of a family cluster. The Lancet, 395(10223), 514-523. https://doi.org/10.1016/S0140-6736(20)30154-9 
Chang, S.L., Harding, N., Zachreson, C., Cliff, O.M., Prokopenko, M. (2020). Modelling transmission and control of the COVID-19 pandemic in Australia. Nature Communications, 11, 5710. https://doi.org/10.1038/s41467-020-19393-6

Chen, N., Zhou, M., Dong, X., Qu, J., Gong, F., Han, Y., Qiu, Y., Wang, J., Liu, Y., Wei, Y., Xia, J., Yu, T., Zhang, X., \& Zhang, L. (2020). Epidemiological and clinical characteristics of 99 cases of 2019 novel coronavirus pneumonia in Wuhan, China: a descriptive study. The Lancet, 395(10223), 507-513. https://doi.org/10.1016/S0140-6736(20)30211-7

Danon, L., Brooks-Pollock, E., Bailey, M., Keeling, M. (2020). A spatial model of CoVID-19 transmission in England and Wales: early spread and peak timing. MedRxiv. https://doi.org/10.1101/2020.02.12.20022566

Dinas Kesehatan Kalbar. (2020). Jumlah Terpapar COVID-19 di Kalimantan Barat. https://dinkes.kalbarprov.go.id/covid-19/

Direktorat Pengembangan Kawasan Pemukiman, Ditjen Cipta Karya Kementerian PUPR. (2020). Kebijakan Kota Baru Pontianak. http://sim.ciptakarya.pu.go.id/kotabaru/site/kebijakankotabaru/1

Downs, J., Horner, M.W. (2012). Probabilistic potential path trees for visualizing and analyzing vehicle tracking data. Journal of Transport Geography, 23, 72-80. https://doi.org/10.1016/j.jtrangeo.2012.03.017

Dunn, F.L., Atlanta, G.A. (1957). Pandemic influenza in 1957: Review of international spread of new Asian strain. Journal of the American Medical Association, 166(10), 1140-1148. https://doi.org/10.1001/jama.1958.02990100028006

Edmonds, E, A. (2008). Reflections on the Nature of Interaction. CoDesign: International Journal of CoCreation in Design and the Arts. 3(3), 139-143.

Grais, R.F., Ellis, J.H., Glass, G.E. (2003). Assessing the impact of airline travel on the geographic spread of pandemic influenza. European Journal of Epidemiology, 18(11), 1065-1072. https://doi.org/10.1023/A:1026140019146

Grais, R.F., Ellis, J.H., Glass, G.E. (2003). Assessing the impact of airline travel on the geographic spread of pandemic influenza. European Journal of Epidemiology, 18(11), 1065-1072. https://doi.org/10.1023/A:1026140019146

Guan, W., Ni, Z., Hu, Y., Liang, W., Ou, C., He, J., Liu, L., Shan, H., Lei, C., Hui, D.S.C., Du, B., Li, L., Zeng, G., Yuen, K.Y., Chen, R., Tang, C., Wang, T., Chen, P., Xiang, J., ... Zhong, N. (2020). Clinical characteristics of coronavirus disease 2019 in China. New England Journal of Medicine, 382(18), 1708-1720. https://doi.org/10.1056/NEJMoa2002032

Hanneman, R, A., Riddle, M. (2005). Introduction to social network methods. Riverside, CA: University of California. http://faculty.ucr.edu/ hanneman/

Hsu, C-I., Shih, H-H. (2008). Small-world Theory in the Study of Network Connectivity and Efficiency of Complementary International Airline Alliances. Journal of Air Transport Management, 14, 123-129. https://doi.org/10.1016/j.jairtraman.2008.02.007

Huang, C., Wang, Y., Li, X., Ren, L., Zhao, J., Hu, Y., Zhang, L., Fan, G., Xu, J., Gu, X., Cheng, Z., Yu, T., Xia, J., Wei, Y., Wu, W., Xie, X., Yin, W., Li, H., Liu, M., ... Cao, B. (2020). Clinical features of patients infected with 2019 novel coronavirus in Wuhan, China. The Lancet, 395(10223), 497-506. https://doi.org/10.1016/S0140-6736(20)30183-5

Inaida, S., Yasui, Y., Tada, Y., Taniguchi, K., Okabe, N. (2011). Geographic trends and spread of the pandemic (H1N1) 2009 in the metropolitan areas of Japan studied from the National Sentinel Data. Japanese Journal of Infectious Diseases, 64(6), 473-481.

Indonesian Air Traffic Company. (n.d.). Bandara Internasional Supadio. https://angkasapura2.co.id/id/business_relation/our_airport/21-bandara-internasional-supadio

Indonesian Shipping Company. (n.d.). Schedule and ticket reservation for ship travelling. https://www.pelni.co.id/reservasi-tiket 
Indonesian Tourism. (2020). Number of airports in Indonesia, 20 most busy!. https://pariwisataindonesia.id/berita/jumlah-bandara-di-indonesia-20-paling-sibuk/

Jia, J.S., Lu, X., Yuan, Y., Xu, G., Jia, J., Christakis, N.A. (2020). Population flow drives spatio-temporal distribution of COVID-19 in China. Nature, 582(7812), 389-394. https://doi.org/10.1038/s41586-020-2284-y

Lawyer, G. (2016). Measuring the potential of individual airports for pandemic spread over the world airline network. BMC Infectious Diseases, 16(1), 1-10. https://doi.org/10.1186/s12879-016-1350-4

Lee, V.J., Chiew, C.J., Khong, W.X. (2020). Interrupting transmission of COVID-19: lessons from containment efforts in Singapore. Journal of Travel Medicine, 27(3), 1-5. https://doi.org/10.1093/jtm/taaa039

Lee, Y. (1998). Highway network connectivity, traffic flow pattern, and economic development of China's Hainan Island. Asian Geographer, 17(1-2), 115-126. https://doi.org/10.1080/10225706.1998.9684039

Li, Q., Guan, X., Wu, P., Wang, X., Zhou, L., Tong, Y., Ren, R., Leung, K.S.M., Lau, E.H.Y., Wong, J.Y., Xing, X., Xiang, N., Wu, Y., Li, C., Chen, Q., Li, D., Liu, T., Zhao, J., Liu, M., ... Feng, Z. (2020). Early transmission dynamics in Wuhan, China, of novel coronavirus-infected pneumonia. New England Journal of Medicine, 382(13), 1199-1207. https://doi.org/10.1056/NEJMoa2001316

Li, W, K., Miyoshi, C., Pagliari, R. (2012). Dual-hub network connectivity: An analysis of all Nippon Airways' use of Tokyo's Haneda and Narita airports. Journal of Air Transport Management, 23, 12-16. https://doi.org/10.1016/j.jairtraman.2012.02.002

Mazhar, M., Abid, I., Hussain, S., Shahzad, N., Sohail, M., Jawed, M. (2020). The effects of regional climatic condition on the spread of COVID-19 at global scale. Science of the Total Environment, 739, 140101. https://doi.org/10.1016/j.scitotenv.2020.140101

Merler, S., Ajelli, M. (2010). The role of population heterogeneity and human mobility in the spread of pandemic influenza. Proceedings of the Royal Society B: Biological Sciences, 277(1681), 557-565. https://doi.org/10.1098/rspb.2009.1605

Milne, G.J., Baskaran, P., Halder, N., Karl, S., Kelso, J. (2013). Pandemic influenza in Papua New Guinea: A modelling study comparison with pandemic spread in a developed country. BMJ Open, 3(3), 1-10. https://doi.org/10.1136/bmjopen-2012-002518

Nijkamp, P., Priemus, H., Shefer, D. (2000). Network connectivity and multimodality: The context. Transportation Planning and Technology, 23(3), 179-182. https://doi.org/10.1080/03081060008717647

Peng, Z., Wang, R., Liu, L., Wu, H. (2020). Exploring urban spatial features of COVID-19 transmission in Wuhan based on social media data. ISPRS International Journal of Geo-Information, 9(6). https://doi.org/10.3390/ijgi9060402

Ratcliffe, R. (2020). First coronavirus cases confirmed in Indonesia amid fears nation is ill-prepared for an outbreak. The Guardian. https://www.theguardian.com/world/2020/mar/02/first-coronaviruscases-confirmed-in-indonesia-amid-fears-nation-is-ill-prepared-for-outbreak

Reuters. (2020). Indonesia confirms first cases of coronavirus. https://www.bangkokpost.com/world/1869789/indonesia-confirms-first-cases-of-coronavirus

Schwartz, K.L., Murti, M., Finkelstein, M., Leis, J.A., Fitzgerald-Husek, A., Bourns, L., Meghani, H., Saunders, A., Allen, V., Yaffe, B. (2020). Lack of COVID-19 transmission on an international flight. Cmaj, 192(15), E410. https://doi.org/10.1503/cmaj.75015

Scott, N., Baggio, R., Cooper, C. (2008). Network analysis and tourism: From theory to practice. Channel View Publications, 35. https://doi.org/10.21832/9781845410896

Sokol, M. (2009). Regional connectivity. In R. Kitchin, N. Thrift (Eds.), International Encyclopedia of Human Geography (pp. 165-180). Vol. 9. Oxford UK: Elsevier

Tan, W., Zhao, X., Ma, X., Wang, W., Niu, P., Xu, W., Gao, G.F., Wu, G. (2020). A novel coronavirus genome identified in a cluster of pneumonia cases - Wuhan, China 2019-2020. China CDC Weekly 2(4), 61-62).

The Government of Indonesia. (2008). Government Regulation No. 26 about National Spatial Plan. 
The Government of West Kalimantan. (n.d.). Geoportal Pemerintah Provinsi Kalimantan Barat. http://geospasial.kalbarprov.go.id/jelajah.html

Tian, H., Liu, Y., Li, Y., Wu, C.H., Chen, B., Kraemer, M.U., Li, B., Cai, J., Xu, B., Yang, Q., Wang, B., Yang, P., Cui, Y., Song, Y., Zheng, P., Wang, Q., Bjornstad, O.N., Yang, R., Grenfell, B.T., ... Dye, C. (2020). An investigation of transmission control measures during the first 50 days of the COVID-19 epidemic in China. Science, 368(6491), 638-642. https://doi.org/10.1126/science.abb6105

Tuncer, N., Le, T. (2014). Effect of air travel on the spread of an avian influenza pandemic to the United States. International Journal of Critical Infrastructure Protection, 7(1), 27-47. https://doi.org/10.1016/j.ijcip.2014.02.001

Valleron, A.J., Cori, A., Valtat, S., Meurisse, S., Carrat, F., Boëlle, P.Y. (2010). Transmissibility and geographic spread of the 1889 influenza pandemic. Proceedings of the National Academy of Sciences of the United States of America, 107(19), 8778-8781. https://doi.org/10.1073/pnas.1000886107

Wasserman, S., Faust, K. (1994). Social network analysis: Methods and applications. Cambridge University Press.

Worldometer. (2020). Coronavirus Update Worldwide. https://www.worldometers.info/coronavirus/

Worldometer. (2020). SARS-CoV-2 Transmission. https://www.worldometers.info/coronavirus/transmission/

Zhao, S., Chen, H. (2020). Modeling the epidemic dynamics and control of COVID-19 outbreak in China. Quantitative Biology, 8(1), 11-19. https://doi.org/10.1007/s40484-020-0199-0 